229

Received: September 15, 2017

Accepted: December 12, 2017
Macedonian Journal of Animal Science, Vol. 7, No. 1-2, pp. 13-18 (2017)

ISSN $1857-6907$

e-ISSN $1857-7709$

UDC: 636.39.09]:616.152.11:618.2(497.7)

Original scientific paper

\title{
CHANGES OF BLOOD ACID-BASE INDICATORS IN ALPINE GOATS DURING PREGNANCY
}

\author{
Zvonko Antunović, Josip Novoselec, Marcela Šperanda, Mislav Đidara, \\ Krunoslav Zmaić, Željka Klir \\ Faculty of Agriculture in Osijek, Josip Juraj Strossmayer University of Osijek, \\ V. Preloga 1, 31000 Osijek, Croatia \\ jnovoselec@pfos.hr
}

\begin{abstract}
The aim of the present paper was to determine the changes of acid-base indicators in the blood of Alpine goats during pregnancy. The research included 21 French Alpine goats during winter feeding season. Goats were divided per 7 in the group according to stage of pregnancy (up to 3 months, from 3 to 4 months, and more than 4 months). Feeding of goats was with a mixture of grains and meadow hay. In the blood of goats concentrations acid-base indicators (blood $\mathrm{pH}, \mathrm{BE}($ efc) $)$, blood gases $\left(\mathrm{pCO}_{2}, \mathrm{pO}_{2}, \mathrm{tCO}_{2}\right)$ as well as electrolytes: $\left(\mathrm{Na}^{+}, \mathrm{K}^{+}, \mathrm{Cl}^{-}\right)$and bicarbonate were determined. Afterwards, anion gap (AG), SID (strong ion differences) and $z$-values were estimated. Comparing determined acidbase indicators in the blood of Alpine goats during various stages of pregnancy significant differences were not evident. Acid-base indicators in blood of Alpine goats did not differ compared to reference values, except AG in blood of Alpine goat during $<3$ months of pregnancy $(7.52 \mathrm{mmol} / \mathrm{l})$ as well as SID during investigation. Determined significant high correlation of acid-base indicators in blood of Alpine goats during pregnancy was expected since there are physiological connections and participation of various indicators in the calculation of some of the indicators obtained. More significantly high correlations were determined in goats during higher pregnancy ( $>4$ month) which can be associated with an increased load of animals because of intensive development of the foetus. Mentioned minor changes of acid-base indicators in the blood of Alpine goats showed a significant resistance on the occurrence metabolic disease.
\end{abstract}

Key words: acid-base status; blood; goat; stage of pregnancy

\section{ПРОМЕНА ВО КРВНИТЕ КИСЕЛО-БАЗНИ ИНДИКАТОРИ КАЈ КОЗИ ОД РАСАТА АЛПИНА ЗА ВРЕМЕ НА ГРАВИДНОСТ}

Целта на овој труд е да ги утврди промените на кисело-базните индикатори во крвта на козите од расата алпина за време на гравидност. Истражувањето вклучило 21 коза од француската раса алпина за време на зимската прехранбена сезона. Козите биле поделени на 3 групи, секоја група со по 7 кози, според степенот на гравидноста (до 3 месеци, од 3 до 4 месеци, и повеќе од 4 месеци). Козите биле хранети со смеса од зрно и ливадско сено. Беше утврдена концентрација на кисело-базните индикатори (рН на крвта, ВЕ) и извршена анализа на гасовите во крвта: $\mathrm{pCO}_{2}, \mathrm{pO}_{2}, \mathrm{tCO}_{2}$, како и на електролитите: $\mathrm{Na}+, \mathrm{K}^{+}, \mathrm{Cl}^{-}$и бикарбонатите. Потоа беа вреднувани анјонскиот јаз, SID (силни јонски разлики) и z-вредностите. Споредувајќи ги кисело-базните индикатори утврдени во крвта на козите од расата алпина во различни фази на гравидност, не беа забележани суштински разлики. Кисело-базните индикатори во крвта на козите не се разликуваат споредени со референтните вредности, освен анјонскиот јаз во крвта во периодот до 3 месеци гравидност (7.52 mol/l). Утврдената значително висока корелација на кисело-базните индикатори во крвта на козите од расата алпина за време на гравидноста беше очекувана, затоа што постои физиолошка поврзаност и бидејќи во пресметувањето на некои добиени вредности учествуваат различни индикатори. Уште поважно е тоа што високи корелации беа утврдени кај козите во текот на понапредна гравидност (по 4 месец), што може да се поврзе со зголемениот напор на животните поради интензивниот развој на фетусот. Спомнатите помали промени на кисело-базните индикатори во крвта на козите од расата алпина укажуваат дека постои значителна отпорност кон појава на метаболична болест.

Клучни зборови: кисело-базен статус; крв; коза; фаза од гравидност

\section{INTRODUCTION}

Alpine goat is known for its high potential for milk production and quality adaptation to the new holding conditions. In Croatia, the Alpine goats are bred for nearly 35 years. In the beginning the population was in the little flocks, while today it significantly increased (Antunović et al., 2012). According to the Croatian Agricultural Agency (CAA) in 
the Republic of Croatia, in year 2016 from total breeding goats, which were accompanied by selection work (6519 heads in 94 goat breeders), a significant portion was related to the Alpine goats, $68.49 \%$ ( 4465 heads in 56 goat breeders). The average the size flocks in Alpine was 80 animals. The determined index of kidding in Alpine goats was 1.00 , and the litter size 1.08, while the kids in the field test (average 105 days) had the average birth weight of $3.52 \mathrm{~kg}$, average daily gain of $220 \mathrm{~g}$, and the final body weight of $27.18 \mathrm{~kg}$. Through complete 2625 lactations in Alpine goats, with an average lactation length of 265 days and milking period of 237 days, the overall average milk production during lactation was $678.49 \mathrm{~kg}$ with an average of $3.33 \%$ fat and $3.02 \%$ protein (CAA, 2017).

Knowing and understanding the metabolic processes in the animal organism are very important for rules of managing and possible elimination of mistakes caused by improper rearing or feeding. Above mentioned can often lead to a decline in productivity and health disorders. This is particularly pronounced during stressful periods, like pregnancy. In high pregnant goats with more foetuses can often get to the metabolic diseases (Rook, 2000). Most often those are pregnant toxaemia before and ketosis after birth (Metthews, 1990; Bostedt and Hamadeh, 1990). Reliable parameter of early toxaemia in highly pregnant Murciano-Granadina goats may be indicators of acid-base balance in the blood: $\mathrm{pH}$, bicarbonate concentration, base excess and anion gap (Gonzalez et al., 2012).

Acid-base balance is vital to maintaining an animal's blood $\mathrm{pH}$ and its health state (Fetmann, 2007). Maintaining normal hydrogen ion concentration in the extracellular fluid is one of the basic homeostatic mechanisms of the body. Homeostatic changes in body of pregnant animals begin at the $4^{\text {th }}$ month of pregnancy, and are particularly pronounced in two weeks before partum (Castillo et al., 1998). Very few research involving the complete acid-base indicators in the blood of pregnant goats (Antunović et al., 2011; Gonzalez et al., 2012).

The aim of this paper is to determine the changes of acid-base indicators in the blood of Alpine goats during pregnancy.

\section{MATERIAL AND METHODS}

\section{Experimental goats and their management}

The research included 21 French Alpine goats. Goats were 4 years old, healthy and in good condition. Goats were in the third pregnancy with a single foetus and fertilized with the same buck. The research was conducted during the winter feeding sea- son on the family farm in Slavonia. Goats were divided according to the stage of pregnancy per 7 in the group as follows: up to 3 months, from 3 to 4 months and more than 4 months of pregnancy. Goats were housed together in groups in boxes, depending of the pregnancy. Feeding of goats was with a mixture of grains (50\% corn and 50\% barley) at the quantity of $1 \mathrm{~kg}$ and meadow hay ad libitum. Goats were also consuming salt and water ad libitum. Animals used in this study were maintained in facilities approved by the Croatian Association for Accreditation of Laboratory Animal Care, and in accordance with current regulations and standards issued by the Croatian Ministry of Agriculture.

\section{Blood collection and analyses}

Blood was collected from the jugular vein into a sterile vacuum tubes with balanced heparin. Acidbase indicators determined on automatic analyzer RapidLab 348, on the principle of ion-selective electrodes. From the acid-base indicators were determined blood $\mathrm{pH}$, excess of extracellular fluid bases $\left(\mathrm{BE}_{(\mathrm{efc})}\right)$, blood gases $\left(\mathrm{pCO}_{2}, \mathrm{pO}_{2}, \mathrm{tCO}_{2}\right)$, electrolytes $\left(\mathrm{Na}^{+}, \mathrm{K}^{+}, \mathrm{Cl}^{-}\right)$and bicarbonate $\left(\mathrm{HCO}_{3}{ }^{-}\right)$. After that, the plasma was separated by centrifugation (10 $\mathrm{min})$ at 3000 revolutions/min on centrifuge Rotofix $32 \mathrm{~A}$ (Hettich). In the blood plasma concentrations of the total proteins were determined with Olympus System Reagents (OSR), manufactured and distributed by Olympus Diagnostic $\mathrm{GmbH}$ (Irish Branch), Lismeehan, Ireland, manufactured for Olympus Diagnostic GmbH, Hamburg, using Olympus AU 400 apparatus.

Strong ion difference (SID) was calculated using the formula: $\left(\mathrm{Na}^{+}+\mathrm{K}^{+}\right)-\mathrm{Cl}^{-}$by Stewart (1983), the $z$-value by the formula SID/Na by Whitehair et al. (1995) and anion gap (AG) by calculation: $\left(\mathrm{Na}^{+}\right.$ $\left.+\mathrm{K}^{+}\right)-\left(\mathrm{Cl}^{-}+\mathrm{HCO}_{3}^{-}\right)$according to Kaneko et al. (2008). Blood serum of weak anions and cations $\left(A_{\text {tot }}\right)$ was calculated by multiplying the total protein $(\mathrm{g} / \mathrm{dl})$ by 2.9 (Constable, 1999; Waller and Lindinger, 2005).

\section{Statistical analysis}

The results were statistically evaluated by using LSD test (Statistica, 2008) to determine the effect of pregnancy stage of goats on acid-base indicators. Results were expressed as mean (mean) and standard deviation (SD). Differences were considered as significant at the level of $(P<0.05)$ or less. Pearson's correlation method was used to assess the 
relation between blood acid-base indicators of Alpine goats in different pregnancy stage.

\section{RESULTS AND DISCUSSION}

Table 1 shows the parameters of acid-base balance in the blood of goats as pregnancy progressed. Comparing changes in acid-base balance indicators obtained in the blood of goats at different pregnancy stages, it is evident that there were no significant differences. Significantly decrease of total protein over the pregnancy and lactation could be explained by a rapid extraction of immunoglobulin from the plasma during the last few months of pregnancy when colostrum is being formed in the mammary gland (Kaneko et al., 2008) as well as the increased needs for proteins for the foetus development (Castillo et al., 1997).

Table 1

Influence of pregnancy stage of goats on blood acid-base indicators

\begin{tabular}{|c|c|c|c|c|}
\hline \multirow{2}{*}{ Parameter } & \multicolumn{3}{|c|}{ Pregnancy stage (mean $\pm \mathrm{sd}$ ) } & \multirow{2}{*}{$\begin{array}{l}\text { Reference values } \\
\text { (Castillo et al., 2000) }\end{array}$} \\
\hline & $<3$ months & $3-4$ months & $>4$ month & \\
\hline $\mathrm{pH}$ & $7.38 \pm 0.06$ & $7.38 \pm 0.05$ & $7.39 \pm 0.04$ & 7.353 \\
\hline $\mathrm{Na}^{+}, \mathrm{mmol} / \mathrm{l}$ & $147.00 \pm 1.73$ & $148.17 \pm 2.11$ & $147.60 \pm 2.35$ & $147.0-157.0^{*}$ \\
\hline $\mathrm{K}^{+}, \mathrm{mmol} / \mathrm{l}$ & $4.26 \pm 0.21$ & $4.28 \pm 0.42$ & $4.27 \pm 0.32$ & $4.00-5.80^{*}$ \\
\hline $\mathrm{Cl}^{-}, \mathrm{mmol} / \mathrm{l}$ & $114.85 \pm 9.75$ & $113.84 \pm 5.54$ & $112.16 \pm 1.80$ & $102.0-114.0 *$ \\
\hline $\mathrm{HCO}_{3}{ }^{-}, \mathrm{mmol} / \mathrm{l}$ & $28.90 \pm 2.04$ & $28.97 \pm 1.94$ & $28.97 \pm 1.88$ & 26.14 \\
\hline $\mathrm{pCO}_{2}, \mathrm{kPa}$ & $6.61 \pm 1.00$ & $6.71 \pm 0.63$ & $6.22 \pm 0.81$ & $48.76 \mathrm{~mm} \mathrm{Hg}$ \\
\hline $\mathrm{pO}_{2}, \mathrm{kPa}$ & $4.91 \pm 0.86$ & $4.71 \pm 0.36$ & $5.02 \pm 0.52$ & - \\
\hline $\mathrm{tCO}_{2}, \mathrm{mmol} / \mathrm{l}$ & $32.20 \pm 1.97$ & $32.35 \pm 1.73$ & $31.67 \pm 2.32$ & - \\
\hline $\mathrm{O}_{2}$ saturation, $\%$ & $68.49 \pm 12.07$ & $66.77 \pm 6.20$ & $71.98 \pm 8.43$ & - \\
\hline $\mathrm{BE}_{(\mathrm{efc})}, \mathrm{mmol} / \mathrm{l}$ & $6.06 \pm 2.23$ & $6.10 \pm 2.17$ & $5.92 \pm 2.30$ & - \\
\hline Total protein, $\mathrm{g} / \mathrm{l}$ & $77.73 \pm 5.09^{\mathrm{a}}$ & $71.02 \pm 4.56^{\mathrm{b}}$ & $65.87 \pm 7.21^{\mathrm{b}}$ & $59.0-82.0$ \\
\hline
\end{tabular}

sd - standard deviation; SID - strong ion difference; *Tschour et al. (2008); ab $(\mathrm{P}<0.05)$

There is a lack of research about acid-base balance in the blood of goats. Antunović et al. (2011) found similar values of $\mathrm{pH}, \mathrm{Na}, \mathrm{K}, \mathrm{pCO}_{2}$ and $\mathrm{pO}_{2}$, lower $\mathrm{Cl}$ and $\mathrm{tCO}_{2}$ as well as higher content of anion gap, SID and $z$-values in high pregnant Alpine goats. Mentioned changes in comparison with present study may be related with effect of stage of pregnancy. Compared to results from the present study Gonzalo et al. (2012) found in the blood of Murciana-Granadina goats lower $\mathrm{pH}$ value (7.36), $\mathrm{HCO}_{3}(23.0 \mathrm{mmol} / \mathrm{l}), \mathrm{Na}(142.5 \mathrm{mmol} / \mathrm{l}), \mathrm{K}(4.18$ $\mathrm{mmol} / \mathrm{l})$ and $\mathrm{Cl}(107.50 \mathrm{mmol} / \mathrm{l})$, as well as similar value of anion gap $(10.85 \mathrm{mmol} / \mathrm{l})$. The normal range for $\mathrm{pH}$ values in mammals are from 7.3 to 7.44 (Houpt, 1989). Values of $\mathrm{pH}$ in blood depend on the relative concentration of carbonic acid and base bicarbonates in blood (Coppock et al., 1982). Also, there were no significant differences for most indicators acid-base balance in comparison with the reference values according to Castillo et al. (2000), except for anion gap and SID (Figure 1). According to Kaneko et al. (2008) recommended value for the anion gap in goats is $10-20 \mathrm{mmol} / \mathrm{l}$, but for SID values is $40.00 \mathrm{mmol} / \mathrm{l}$ (Castillo et al., 2000). Lower values of the AG achieved in stages pregnancy to the $3^{\text {rd }}$ months and SID during investigation may depend on several factors. Therefore, according to the recommendations of Castillo et al. (1998), in assessing the acid-base balance of the blood, moving anion gap should be taken with caution because its values are very dependent on the movement of content bicarbonate, albumin and $\mathrm{pCO}_{2}$. Lower values of the SID may be connected with higher concentration of $\mathrm{Cl}^{-}$in blood of goats during pregnancy which is probably related to food. Naimly, Hu and Murphy (2004.) were obtained that blood $\mathrm{Cl}$ concentrations depending about nutrition consumption. Las et al. (2007) showed that the acid-base status of the extracellular fluid is directly affected by the concentrations of strong basic actions and strong acid anions that absorbed into the blood stream from diet. Apper-Bossard et al. (2009) noted that chlorine is the main ion implicated in the acid-base regulation. 


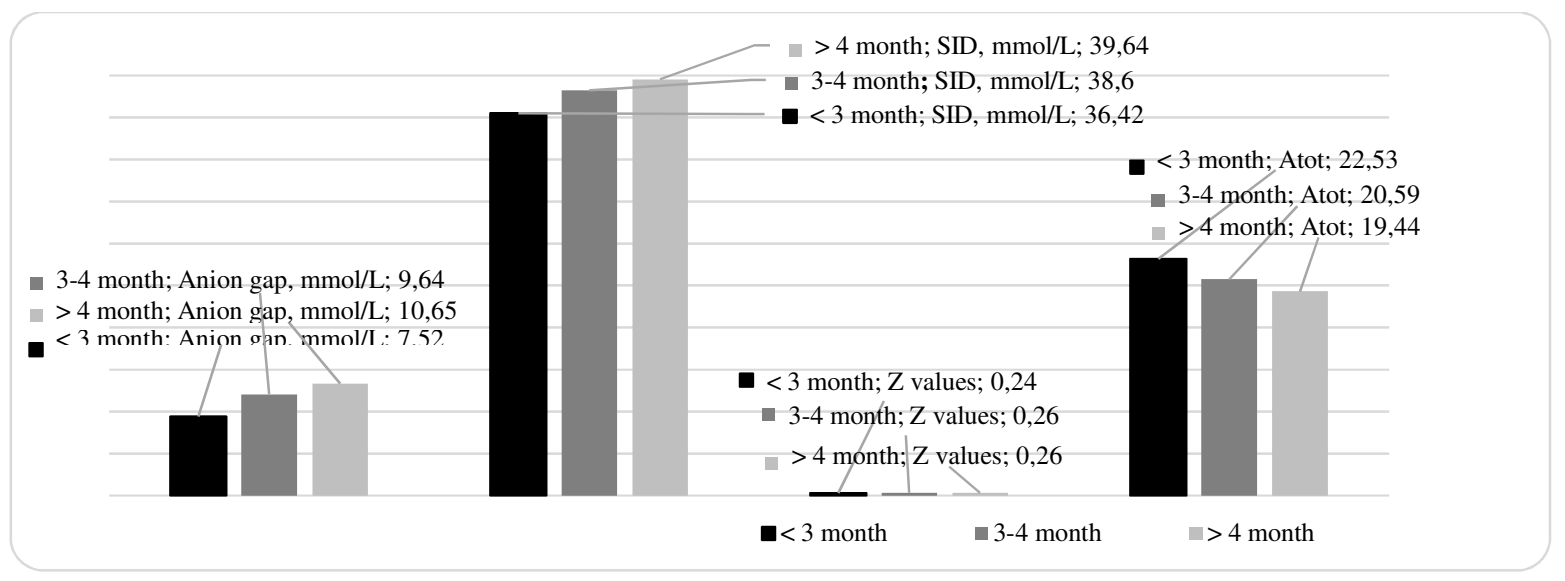

Fig. 1. Influence of pregnancy stage of goats on some of blood acid-base indicators

In blood of Alpine goats during lactation Antunović et al. (2017) determined similar values of acid-base balance ( $\mathrm{pH}: 7.37-7.39 ; \mathrm{pCO}_{2}$ 6.1-6.75; $\mathrm{pO}_{2}$ 3.85-5.39). Mentioned minor changes of acidbase indicators in the blood of goats showed a significant resistance on the occurrence of metabolic disease, which is consistent with the conclusions by Drackley et al. (1989).

Determined significantly high correlation of acid-base indicators in blood of Alpine goats during different pregnancy stage (Table 2) were expected since their physiological connection and the participation of various indicators in the calculation of some of the obtained indicators, such as AG, SID and $z$-value, were constant.

Slightly more signifycantly high correlation was found in goats during higher pregnancy ( $>4$ months) which can be related to an increased load of animals for intensive development of the foetus.

Table 2

Significant correlations between investigated blood acid-base indicators in different pregnancy stage of Alpine goats

\begin{tabular}{|c|c|c|c|c|c|}
\hline Ratio & $<3$ months & Ration & 3-4 months & Ration & $>4$ months \\
\hline $\mathrm{pH}: \mathrm{pCO}_{2}$ & -0.892 & $\mathrm{pH}: \mathrm{pCO}_{2}$ & -0.831 & $\mathrm{pH}: \mathrm{pCO}_{2}$ & -0.837 \\
\hline $\mathrm{pCO}_{2}: \mathrm{O}_{2}$ & 0.864 & $\mathrm{pH}: \mathrm{K}$ & -0.814 & $\mathrm{pH}: \mathrm{O}_{2}$ & -0.969 \\
\hline $\mathrm{pO}_{2}: \mathrm{O}_{2}$ & 0.938 & $\mathrm{pO}_{2}: \mathrm{O}_{2}$ & 0.879 & $\mathrm{pCO}_{2}: \mathrm{pO}_{2}$ & -0.897 \\
\hline $\mathrm{HCO}_{3}: \mathrm{BE}$ & 0.993 & SID:Cl & -0.943 & $\mathrm{pCO}_{2}: \mathrm{K}$ & 0.877 \\
\hline $\mathrm{HCO}_{3}: \mathrm{tCO}_{2}$ & 0.799 & SID:AG & 0.965 & $\mathrm{pCO}_{2}: \mathrm{O}_{2}$ & -0.969 \\
\hline $\mathrm{BE}: \mathrm{tCO}_{2}$ & 0.851 & $\mathrm{Cl}: \mathrm{AG}$ & -0.838 & $\mathrm{pO}_{2}: \mathrm{O}_{2}$ & 0.956 \\
\hline SID:Cl & -0.983 & $\mathrm{Cl}: \mathrm{z}$ & -0.943 & Na:AG & 0.885 \\
\hline SID:AG & 0.977 & AG:z & 0.965 & $\mathrm{Na}: \mathrm{z}$ & 0.845 \\
\hline $\mathrm{Cl}: \mathrm{AG}$ & -0.972 & & & Na:SID & 0.845 \\
\hline $\mathrm{Cl}: \mathrm{z}$ & -0.983 & & & $\mathrm{~K}: \mathrm{O}_{2}$ & -0.784 \\
\hline \multirow[t]{7}{*}{ AG:z } & 0.977 & & & $\mathrm{HCO}_{3}: \mathrm{BE}$ & 0.996 \\
\hline & & & & $\mathrm{HCO}_{3}: \mathrm{tCO}_{2}$ & -0.756 \\
\hline & & & & $\mathrm{tCO}_{2}: \mathrm{BE}$ & 0.927 \\
\hline & & & & SID:Cl & -0.832 \\
\hline & & & & SID:AG & 0.934 \\
\hline & & & & $\mathrm{Cl}: \mathrm{z}$ & -0.832 \\
\hline & & & & AG:z & 0.934 \\
\hline
\end{tabular}




\section{CONCLUSION}

Stage of pregnancy had no significant differences on acid-base indicators in the blood of goats. Comparing the analyzed indicators of acid-base status of pregnant Alpine goats with the reference values, minor differences were determined, except lower AG in goats during $<3$ months of pregnancy and SID during investigation. Determined significantly high correlation of acid-base indicators in blood of Alpine goats, during different pregnancy stage, were expected since their physiological connection and the participation of various indicators in the calculation of some of the obtained indicators were constant. Slightly more significantly high correlation was found in goats during higher pregnancy ( $>4$ months) which can be related to an increased load of animals for intensive development of the foetus. Mentioned changes of acid-base indicators in the blood of Alpine goats showed a significant resistance on metabolic disease.

Acknowledgement: This paper developed within the project funded by the Ministry of Agriculture and Ministry of Science, Education and Sports of the Republic of Croatia.

\section{REFERENCES}

[1] Antunović, Z., Novoselec, J., Šperanda, M., Đidara, M., Klir, Ž., Kopačin, T.: Blood acid-base balance and hematological parameters in pregnant goats from organic farming. Krmiva, 53 (4) 151-156 (2011).

[2] Antunović, Z., Novoselec, J., Klir, Ž.: Sheep and goat breeding in the Republic of Croatia - present situation and perspectives. Krmiva, 54 (3) 99-109 (2012).

[3] Antunović, Z., Šperanda, M., Novoselec, J., Đidara, M., Mioč, B., Klir, Ž., Samac, D.: Blood metabolic profile and acid-base balance of dairy goats and their kids during lactation. Vet. Arhiv, 87 (1) 43-55 (2017).

[4] Apper-Bossard, E., Peyraud, J. L., Dourmad, J. Y.: Effects of dietary cation-anion difference on performance and acid-base status: a review. Inra Prod. Anim., 22, 117-130 (2009)

[5] Bostedt, H., Hamadeh, M. E.: Zur Bedeutung der graviditätsbedingten Ketonurie bei Schaf und Ziege. Tierärztliche Praxis 18, 125-129 (1990).

[6] Castillo, C., Hernandez, J. R., Lopez, M., Miranda, M., Garcia-Partida, P., Benedito, J. L.: Relationship between venous $\mathrm{pH}$, serum calcium and proteins in the course of anoestrus, pregnancy and lactation in the ewe. Archiv für Tierzucht 40, 257-263 (1997).
[7] Castillo, C., Garcia-Partida, P., Hernandez, J., Benedito, J. L.: Application of Fencl's equations in the acid-base balance changes related to pregnancy on ewe. Vet. Med., 43, 27-31 (1998)

[8] Castillo, C., Hernandez, J., Benedito, J. L., Lopez-Alonso, M., Miranda, M., Gutierrez-Panizo, C., Sotillo, J.: Quantitative evaluation of acid-base balance on milk producing goats: Effect of sex and milk yield. Vet. Med., 45, 241-246 (2000).

[9] Castillo, C., Hernandez, J., Bravo, A., Lopez-Alonso, M., Pereira, V., Benedito, J. L.: Oxidative status during late pregnancy and early lactation in dairy cows. Vet. J., 169, 286-292 (2003).

[10] Constable, P. D.: Clinical assessment of acid-base status. Strong ion difference theory. Vet. Clin. North America, Food Anim. Pract. 15, 297-311 (1999).

[11] Coppock, C. E., Grant, P. A., Portzer, S. J., Charles, D. A., Escobosa, A.: Lactating dairy cow responses to dietary sodium, chloride and bicarobonate during hot weather. $J$. Dairy Sci., 65, 566 (1982).

[12] CAA-Croatian Agricultural Agency: Annual report 2016. Breeding of sheep, goats and small animals. Križevci. pp. 88 (2017).

[13] Drackley, J. K., Kim, Y. K., Strang, B. D., Young, J. W.: Metabolic response of lactating goats to feed restriction and dietary 1,3 butanediol. J. Dairy Sci., 72: 204 (1989).

[14] Fetmann, M. J.: Fluid and electrolyte metabolism. In: Thrall M.A. (ed.), Haematology and Veterinary Clinical Biochemistry. Roca, Sao Paulo, 2007, pp. 311-334.

[15] Gonzalez, F. H. D., Hernandez, F., Madrid, J., MartinezSubiela, S., Ceron, J. J., Tecles, F.: Acid-base and electrolyte status during early induced pregnancy toxaemia in goats, Vet. Journal 193, 598-599 (2012).

[16] Houpt, T. R.: Water, electrolytes and acid base balance. In: Dukes Physiology of Domestic Animals (ed. Swenson, M.J.), $10^{\text {th }}$ ed. Cornell University Press, Itacha, NY, 1989, pp. 486-506.

[17] Hu, W., Murphy, M. R.: Dietary cation-anion difference effects on performance and acid-base status of lactating dairy cows: a meta-analysis. J. Dairy Sci. 87, 2222-2229 (2004).

[18] Kaneko, J. J., Harvey, J. W., Bruss, M. L.: Clinical Biochemistry of Domestic Animals, 6th ed. Elsevier/Academic Press, Amsterdam, 2008, pp. 931.

[19] Las, J. E., Odongo, N. E., Lindinger, M. I., Alzahal, P., Shoveller, A. K., Matthews, J. C., Mcbride, B. W.: Effects of dietary strong acid anion challenge on regulation of acid-base balance in sheep. J. Anim. Sci., 85, 2222-2229 (2007).

[20] Metthews, J. G.: Ketosis in dairy goats. Goat Veterinary Society Journal 11, 71-74 (1990).

[21] Rook, J. S.: Pregnancy toxaemia of ewes, does, and beef cows. Vet. Clinics North America. Food Anim. Prac., 16, 293-317 (2000). 
[22] Statistica-Stat Soft, Inc. version 8.0, 2008, www.statsoft.com.

[23] Stewart, P. A.: Modern quantitative acid-base chemistry. Canadian J. Phys. Pharmac., 61, 1441-1461 (1983).

[24] Tschuor, A. C., Riond, B., Braun, U., Lutz, H.: Hämatologische und klinisch-chemische Referenzwerte für adulte Ziege und Schafe. Schweiz Archive Tierheik, 287-295 (2008).
[25] Waller, A., Lindinger, M. I.: Physiochemical analysis of acid-base status during recovery from high-intensity exercise in Standardbred racehorses. Equine Comp. Exerc. Physiol., 2, 119-127 (2005).

[26] Whitehair, K. A., Haskins, S. C., Whitehair, J. G., Pascoe, P. J.: Clinical applications of quantitative acid-base chemistry. J. Vet. Internal Med., 9, 1-11 (1995). 